UDC 614.76 (77)

DOI: 10.21668/health.risk/2017.2.07.eng

\title{
POPULATION HEALTH RISK RELATED TO INCREASED CONTENT OF BENZPYRENE IN SOIL
}

\author{
V.V. Suchkov ${ }^{1}$, S.A. Khotimchenko ${ }^{2}$, O.V. Sazonova ${ }^{1,3}$, D.O. Gorbachev ${ }^{1}$, \\ T.K. Ryazanova ${ }^{1}$, E.A. Semaeva ${ }^{1}$
}

${ }^{1}$ Samara State Medical University, 89 Chapayevskaya Str., Samara, 443099, Russian Federation

${ }^{2}$ Federal Research Centre of nutrition and biotechnology, 2/14 Ustinskiy Proezd, Moscow, 109240, Russian Federation

${ }^{3}$ Research Institute of Human Hygiene and Ecology at the Samara State Medical University, 87 Chapayevskaya Str., Samara, 443099, Russian Federation

The article deals with the problem of soil contamination with benzpyrene within sanitary-hygienic zone of an oil refinery plant. We proved that benzpyrene penetrated into soils due to oil-containing wastes and sedimentation of polycyclic aromatic hydrocarbons from powder-gas discharges on soil surface. Benzpyrene concentration detection at the boundary of a sanitary-hygienic zone provides guidelines for determining discharges spread into the atmosphere from stationary sources; it also serves as an indirect parameter characterizing soil self-purification intensity. We treated benzpyrene content in soils as an informative indicator showing soil horizon contamination with polycyclic aromatic hydrocarbons and heavy oil fractions. Over 2015-2016 66 soil samples were taken and analyzed. We detected benzpyrene concentration with Agilent Technologies 7820A GC System «Maestro» gas chromatograph with mass-selective detector Agilent Technologies 5975 Series MSD in full conformity with ISO 18287: 2006. We compared actual benzpyrene concentrations with maximum permissible concentration $(M P C=0.02 \mathrm{mg} / \mathrm{kg})$, confirmed by Hygienic Standard 2.1.7.2041-06. The results of analyzing the samples as per benzpyrene content revealed that it was higher than maximum permissible concentration $(M P C)$ in all of them. Share of samples with benzpyrene content higher than 1.5 MPC varied from $54.5 \%$ to $90.9 \%$ in different seasons. Some places within sanitary-hygienic zone had high benzpyrene concentration in soils reaching 9.85 MPC. High benzpyrene content in soils proves there is persistent soil horizon contamination with polycyclic aromatic hydrocarbons and soil self-purification slows down. And this, in its turn, causes carcinogenic health risk occurrence $\left(1.08 \cdot 10^{-3}-6.55 \cdot 10^{-3}\right)$.

Key words: soil contamination, sanitary-hygienic zone, oil refinery plant, benzpyrene, carcinogen, health risk, maximum permissible concentrations.

Disposal of industrial wastes in large quantities into soil, especially harmful chemical impurities of organic origin, result in gradual decrease in the concentration of humic nitrogen, decelerating or completely stopping multiplication of humifying microorganisms

$[8,11,14]$. Oil refineries operation is accompanied by the formation of oil sludge in considerable volumes, and sewage sludge after mechanical and biological treatment, which are subsequently accumulated in oil pits or disposed at special landfills $[2,6]$. The areas of

(C) Suchkov V.V., Khotimchenko S.A., Sazonova O.V., Gorbachev D.O., Ryazanova T.K., Semaeva E.A., 2017

Vyacheslav V. Suchkov - Candidate of Medical Sciences, assistant at Common Hygiene department (email: slav-vok4us@mail.ru; tel.: +7 (846) 337-55-52).

Sergey A. Khotimchenko - Doctor of Medical Sciences, Professor, temporarily acting as the First Deputy Director (e-mail: hotimchenko@ion.ru; tel.: +7 (495) 698-52-35).

Olga V. Sazonova - Doctor of Medical Sciences, Associate professor, Head (e-mail: ov 2004@ mail.ru; tel.: +7 (846) 332-26-53).

Dmitry O. Gorbachev - Candidate of Medical Sciences, Associate professor at Common Hygiene department (e-mail: dmitriy-426@ rambler.ru; tel.: +7 (846) 337-55-52).

Tatyana K. Ryazanova - Candidate of Pharmaceutical Sciences, assistant at Pharmacy management and Economics department (e-mail: ryazantatyana@mail.ru; tel.: +7 (846) 260-38-06).

Evgenia A. Semaeva - a four-year student at medical and prevention faculty. 
sanitary hygienic zones of oil refineries are moderately polluted with oil products: in the surface soil horizon soil nitrification intensity is reduced, the structure and degradation of nitrifiers and denitrifiers are reduced due to the content of heavy oil fractions and polycyclic aromatic hydrocarbons (PAH) in soil [7, 10]. As studies have shown, PAH are practically resistant to microbial decomposition and remain in the initial concentration in oilcontaminated soil for a long time $[1,7,9]$.

The main representative of PAH being detected in soil is benzpyrene, the first hazard category substance of carcinogenic effect. This harmful impurity enters the soil through air discharges from stationary sources, settling gradually on the soil surface layer. Such contamination occurs primarily within the sanitary-hygienic zone, however, depending on meteorological conditions, benzpyrene can deposit at a long distance from the stationary source. Another reason for benzpyrene penetration in soil is industrial wastes.

Benzpyrene content in soil serves as an informative indicator of soil horizon contamination with PAH and heavy oil fractions. Detection of its concentration at the boundary of sanitary-hygienic zone provides guidelines for determining discharges spread into the atmosphere from stationary sources, and also serves as an indirect parameter characterizing soil self-purification intensity. High concentrations of benzpyrene at the boundary of sanitaryhygienic zones make a considerable contribution to multi-environmental health risks level in location area of a residential zone [3]. Expansion of residential area is especially dangerous, as well as active development of the former sanitary-hygienic zone following its reduction.

The purpose of the study is the sanitaryhygienic assessment of benzpyrene content in the soil on the territory of the sanitaryhygienic zone at the oil refinery with health risk identification.

Materials and methods. Soil samples were taken in the territory of the sanitaryhygienic zone at the Novokuybyshevsk Oil Refinery Plant ("NK NPZ") in four directions: northeastern (NE) - at the distances of 600 and
$1000 \mathrm{~m}$ from the checkpoint; eastern (E) - at the distances of 200, 600 and $1000 \mathrm{~m}$ from the checkpoint; southeastern (SE) - at the distances of 600 and $1000 \mathrm{~m}$ from the stationary source of the oil-dissolved gas discharges; southern (S) - at the distances of 200, 400, 600 $\mathrm{m}$ and $1000 \mathrm{~m}$ from the petroleum products catalyst cracker. The choice of soil sampling points was predicated upon the neighboring location of Novokuybyshevsk city and Lypyagi rural settlement. The soil surface layer was selected by the "envelope" method at $20 \mathrm{~cm}$ depth, according to GOST 17.4.4.02-84 [5]. The mass of one sample made $200 \mathrm{~g}$. In total 66 soil samples were taken and analyzed for the period of 2015-2016. Prior to determining benzpyrene concentrations, all soil samples were subject to pretreatment, in particular, drying at a temperature of $18-20^{\circ} \mathrm{C}$ and ambient relative humidity of $40-60 \%$; sifting through a fine-mesh screen with a cell area of $0.5 \mathrm{~mm}^{2}$; filtering the liquid phase with "white tape" filter. Samples were analyzed with Agilent Technologies 7820A GC "Maestro" system gas chromatograph, with mass-selective detector Agilent Technologies 5975 Series MSD in accordance with the international standard ISO 18287: 2006 [6]. The concentration of benzpyrene was calculated by the ratio of the analyzed sample peak heights to the standard PAH samples dissolved in cyclohexane. The average retention time for benzpyrene prior to peak was 35.23 minutes.

Benzpyrene is a first-category hazard chemical belonging to $2 \mathrm{~A}$ group (carcinogenic agents for human with an extremely high evidence degree), classified by the International Agency for Research on Cancer (IARC). Its molar mass is $252.309 \mathrm{~g} / \mathrm{mol}$, molecular weight is 252.3 (Figure 1). Similar masses exist for benzpyrene-like compounds of $\mathrm{PAH}$ : benzo(b)fluoroanthrene and benzo(k)fluoranthene. Therefore, the concentration of benzpyrene was calculated from the slope ratio of calibration function, minus concentrations of the above substances. Configuration of the obtained chromatogram for the soil sample No. 8 is shown in Fig. 2. 
All the results obtained were grouped by distances and directions from the stationary sources of gross discharges to atmospheric air, as well as from the oil pits. We compared actual concentrations of benzpyrene with the maximum permissible ( $\mathrm{MPC}=0.02 \mathrm{mg} / \mathrm{kg}$ ), approved in the GN 2.1.7.2041-06 [4].

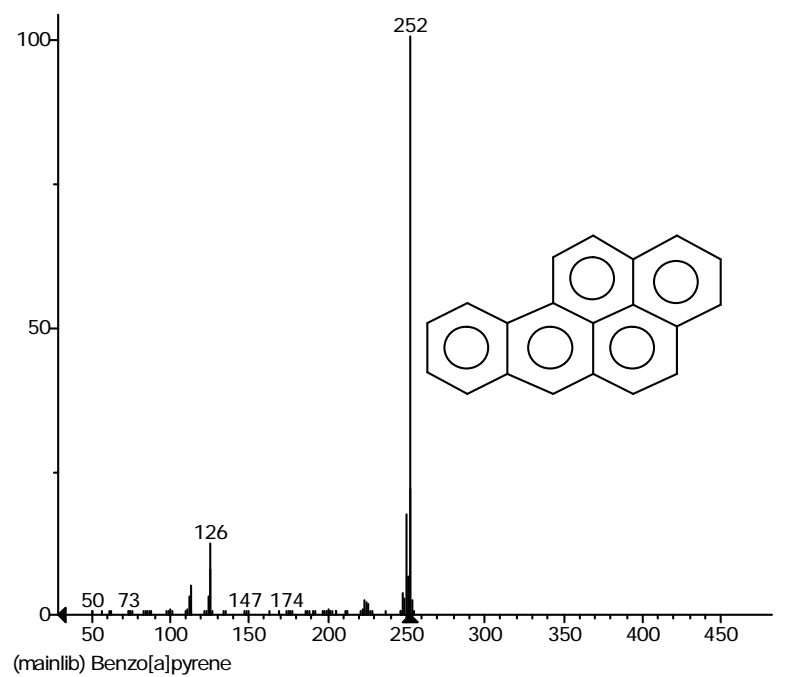

Figure 1. Mass spectrum and structural formula for benzpyrene (NIST 14 mass spectrometry library)

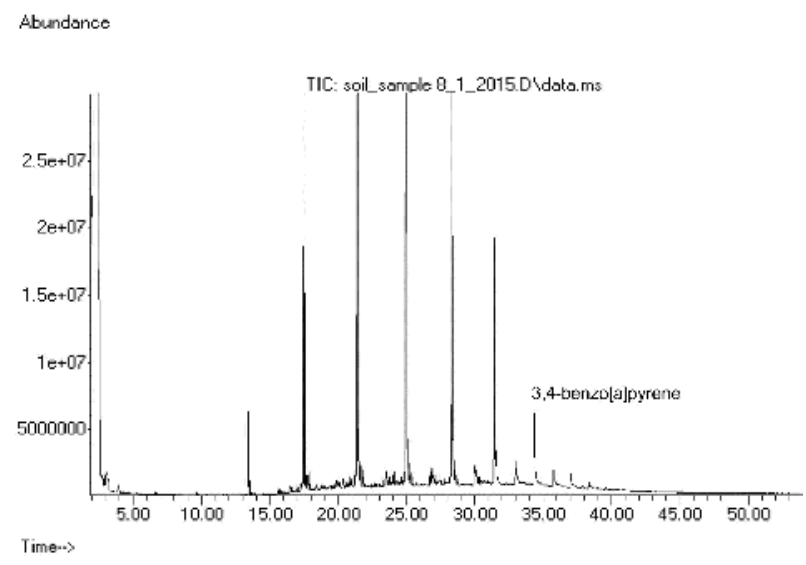

Figure 2. Chromatogram of the soil sample

No. 8 taken in spring 2015.

Analysis of the production and consumption wastes for the oil refinery was carried out according to the annual statistical forms 2-TP (wastes). Health risk was calculated in accordance with the guidelines $\mathrm{P}$ 2.1.10.1920-04 [13]; standard exposure values were used. Statistical data processing was done using $\mathrm{Mi}$ - crosoft Excel 2013 and Statistica 10 Enterprise 10.0.1011.6.

Results and discussion. Novokuibyshevsk Oil Refinery Plant belongs to the first category of hazard, according to SanPiN 2.2.1/2.1.1.1200-03 "Sanitary-hygienic zones and sanitary classification for enterprises, structures and other objects". The basic unit taken for the sanitary-hygienic zone was 1000 $\mathrm{m}$. The consumption and production wastes of the refinery amounted to 28,145 tons for 2014 , and 49,432 tons over 2015. The increase in wastes volumes in 2015 is associated with an increase in oil processing capacity by $56 \%$. Wastes with a high PAH content are formed mainly at washing equipment for storage, processing and transport of oil. It is the sludge after cleaning pipelines and containers (barrels, containers, cisterns and bitumen sprayers) for oil and petroleum products. The big volumes of wastewater, as a result of slurry dilution with industrial water, were exposed to mechanical and bio-treatment. Upon wastewater treatment, sludge settlings containing oil products in the amount of less than $15 \%$ massed 18,470 tons in 2014 , and 40,320 tons in 2015. Sludge settlings in the final stage of disposal are accumulated in oil pits and reservoirs-sedimentation tanks, followed by dumping of oil-containing wastes at landfills, or wastes biodegradation and biotransformation using the components of biostructuring mixture [12].

Oil pits and reservoirs-sedimentation tanks for oil sludge are located in the northwestern part of the oil refinery industrial zone. The minimum distance between the nearest sampling point and the oil pits was $2.4 \mathrm{~km}$. There was no soil sampling done in the northwestern part of the sanitary-hygienic zone, since the nearest residential area 'Mayak' is located at a distance of $6.3 \mathrm{~km}$ from the northwestern border of the oil refinery sanitary-hygienic zone.

When analyzing the laboratory results of the selected samples, it was found that the average concentrations for benzpyrene in soil were higher than MPC: in 2015: $0.0466 \pm$ 
$0.0070 \mathrm{mg} / \mathrm{kg}(2.33 \mathrm{MPC})$, in 2016: $0.0491 \pm$ $0.0068 \mathrm{mg} / \mathrm{kg}$ (2.46 MPC). In all directions from the oil refinery there was a slight increase in benzpyrene concentration (by 0.2-0.5 MPC) in 2016, unlike in 2015. The territory of the eastern part of the sanitary-hygienic zone is more exposed to contamination with PAH: at a distance of $1000 \mathrm{~m}$ from the oil refinery (at the boundary of the sanitary-hygienic zone), we recorded maximum content of benzpyrene: 9.85 MPC. The increasing gradient of benzopyrene content in the eastern direction made 1.8 MPC at increasing the distance from the oil refinery from 200 to $600 \mathrm{~m}$ and $3.5 \mathrm{MPC}$ from 600 to $1000 \mathrm{~m}$.

Table 1

Benzpyrene content $(\mathrm{mg} / \mathrm{kg})$ in the selected samples, depending on the distance to the oil refinery plant

\begin{tabular}{|c|c|c|c|c|c|c|c|}
\hline \multirow{2}{*}{ Sample No. } & \multirow{2}{*}{ Direction and distance to oil refinery } & \multicolumn{3}{|c|}{2015} & \multicolumn{3}{|c|}{2016} \\
\cline { 3 - 8 } & & Spring & Summer & Autumn & Spring & Summer & Autumn \\
\hline 1 & $200 \mathrm{~m}$ to the east & 0,024 & 0,072 & 0,037 & 0,026 & 0,041 & 0,056 \\
\hline 2 & $600 \mathrm{~m}$ to the east & 0,024 & 0,071 & 0,049 & 0,065 & 0,087 & 0,077 \\
\hline 3 & 1000 m to the east & 0,043 & 0,192 & 0,194 & 0,098 & 0,167 & 0,197 \\
\hline 4 & $1000 \mathrm{~m}$ to southeast & 0,024 & 0,051 & 0,055 & 0,059 & 0,043 & 0,053 \\
\hline 5 & $600 \mathrm{~m}$ m to southeast & 0,021 & 0,054 & 0,038 & 0,032 & 0,041 & 0,047 \\
\hline 6 & 200 m to south & 0,021 & 0,045 & 0,042 & 0,036 & 0,037 & 0,041 \\
\hline 7 & 400 m to south & 0,058 & 0,036 & 0,035 & 0,029 & 0,033 & 0,031 \\
\hline 8 & 600 m to south & 0,033 & 0,025 & 0,023 & 0,028 & 0,027 & 0,021 \\
\hline 9 & 1000 m to south & 0,026 & 0,024 & 0,029 & 0,021 & 0,031 & 0,026 \\
\hline 10 & $600 m$ to northeast & 0,061 & 0,024 & 0,026 & 0,025 & 0,034 & 0,027 \\
\hline 11 & 1000 m to northeast & 0,029 & 0,028 & 0,025 & 0,032 & 0,024 & 0,029 \\
\hline
\end{tabular}

In the northeastern part of the sanitaryhygienic zone, the maximum benzpyrene concentrations were recorded in the immediate vicinity of the oil refinery $(600 \mathrm{~m}): 1.85 \mathrm{MPC}$ in 2015 and 1.43 MPC in 2016. In the southern direction from the petroleum products catalyst cracker, benzpyrene level was decreasing by an average gradient of 0.5 MPC with raising the distance from 200 to $600 \mathrm{~m}$. However, at a distance of $1000 \mathrm{~m}$ (at the boundary of the sanitary-hygienic zone), benzpyrene concentration increased slightly to 1.31 MPC. The southeastern direction from the stationary source of the oil-dissolved gas discharges was characterized by the higher content of benzpyrene at increasing the distance from 600 to $1000 \mathrm{~m}$. Data details are presented in Table 1 and Fig. 3.

In 2015 and 2016, the share of samples with the increased MPC level for benzpyrene made $93.55 \%$. In the autumn period, benzpyrene content in 2016 was higher by $9.4 \%$ than in 2015 . In the spring of 2015, the number of samples with benzpyrene level above $1.5 \mathrm{MPC}$ was $54.5 \%$ with an average concentration of 0.042

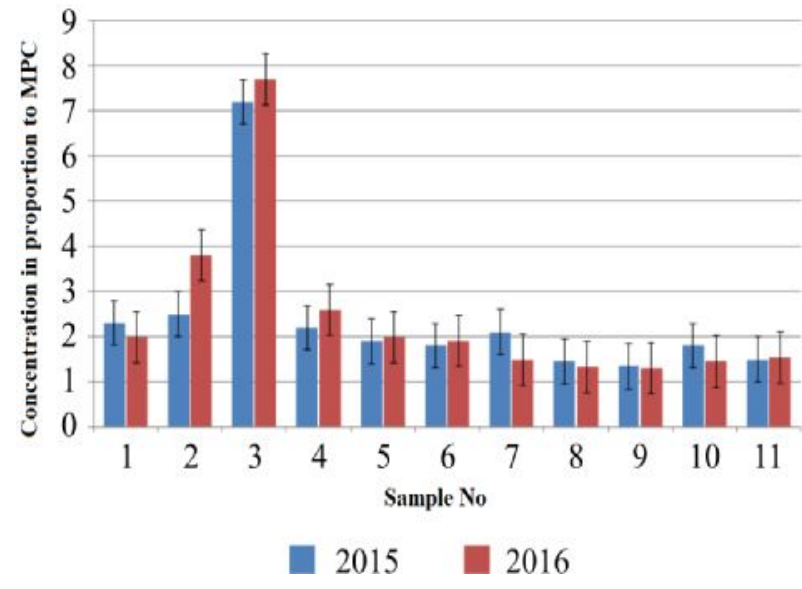

Fig.3. Distribution for benzopyrene concentrations

$\mathrm{mg} / \mathrm{kg}$, in the spring period of 2016: $90.9 \%$ of the average concentration of $0.04 \mathrm{mg} / \mathrm{kg}$. As per benzpyrene content, the soil in the territory of the oil refinery's sanitary-hygienic zone belonged to "hazardous" pollution category, in accordance with SanPiN 2.1.7.1287-03 "Sanitary and epidemiological requirements for soil quality". 
The second way in which benzpyrene enters the soil is PAH discharges settling on the soil surface layer. Depending on meteorological parameters (wind direction and speed, air temperature and humidity), the dispersion range of discharges can both be reduced, limited to the territory of the sanitary-hygienic zone, as well as expanded, including to the settlement and residential areas. During the period of 2015-2016, West wind prevailed in the oil refinery's territory (26\%) with an average speed of $3.4 \mathrm{~m} / \mathrm{s}$. Along with discharges from the stationary sources PAHs enter the atmos- phere with the exhausts of motor vehicles. This may be the reason for an increased content of benzpyrene in the soil at the boundary of the sanitary-hygienic zone in the eastern direction from Oil Refinery Plant, where Novokuibyshevsk is located in the immediate vicinity.

Analyzing and grouping the obtained results per distances from Oil Refinery, we calculated the data for health risk levels (Table 2).

Table 2

Data for carcinogenic and non-carcinogenic health risks, obtained as a result of studying benzpyrene content in soil, depending on the distance to Oil Refinery Plant

\begin{tabular}{|c|c|c|c|c|c|}
\hline \multirow{2}{*}{ Sample No. } & \multirow{2}{*}{$\begin{array}{c}\text { Direction and distance to oil } \\
\text { refinery }\end{array}$} & \multicolumn{2}{|c|}{2015} & \multicolumn{2}{|c|}{2016} \\
\cline { 3 - 5 } & $200 \mathrm{~m}$ to the east & $1,89 \cdot 10^{-3}$ & 7,76 & $1,75 \cdot 10^{-3}$ & 7,18 \\
\hline 1 & $600 \mathrm{~m}$ to the east & $2,04 \cdot 10^{-3}$ & 8,40 & $3,25 \cdot 10^{-3}$ & 13,4 \\
\hline 2 & $1000 \mathrm{~m}$ to the east & $6,08 \cdot 10^{-3}$ & 25,0 & $6,55 \cdot 10^{-3}$ & 27,0 \\
\hline 3 & $1000 \mathrm{~m}$ to southeast & $1,84 \cdot 10^{-3}$ & 7,58 & $2,20 \cdot 10^{-3}$ & 9,04 \\
\hline 4 & $600 \mathrm{~m}$ m to southeast & $1,60 \cdot 10^{-3}$ & 6,59 & $1,70 \cdot 10^{-3}$ & 7,00 \\
\hline 5 & $200 \mathrm{~m}$ to south & $1,53 \cdot 10^{-3}$ & 6,30 & $1,62 \cdot 10^{-3}$ & 6,65 \\
\hline 6 & $400 \mathrm{~m}$ to south & $1,83 \cdot 10^{-3}$ & 7,53 & $1,32 \cdot 10^{-3}$ & 5,43 \\
\hline 7 & $600 \mathrm{~m}$ to south & $1,15 \cdot 10^{-3}$ & 4,73 & $1,08 \cdot 10^{-3}$ & 4,43 \\
\hline 8 & $1000 \mathrm{~m}$ to south & $1,12 \cdot 10^{-3}$ & 4,61 & $1,11 \cdot 10^{-3}$ & 4,55 \\
\hline 9 & $600 \mathrm{~m}$ to northeast & $1,57 \cdot 10^{-3}$ & 6,48 & $1,22 \cdot 10^{-3}$ & 5,02 \\
\hline 10 & $1000 \mathrm{~m}$ to northeast & $1,16 \cdot 10^{-3}$ & 4,78 & $1,21 \cdot 10^{-3}$ & 4,96 \\
\hline 11 & & & & \\
\hline
\end{tabular}

N o t e : *-carcinogenic risk; $* *$ - non-carcinogenic risk.

All levels of health risk belonged to the fourth range of reference limits, and were unacceptable to people health. The maximum value for carcinogenic risk was obtained at the boundary of the sanitary-hygienic zone in the eastern direction from Oil Refinery. Soil was the source of the air-ground interface secondary pollution. According to residential zone scenario, among all the ways for benzpyrene entering a human body, inhalation route prevailed $(99.96 \%)$. The risk factors for development of non-carcinogenic effects were 6-8 times higher than the threshold value; at the boundary of the sanitary-hygienic zone, in the eastern direction to Oil Refinery, the maximum value reached 25 . High levels of health risks indicate an extreme pollution of habitat in the territory of the sanitary-hygienic zone, and the unconditioned disutility for living, in case if former territory of the sanitary-hygienic zone would be developed after reducing its area. Measures to improve environment can help in decreasing PAHs content in soil and, as a result, the health risk level. Complex of measures should include: liquidation of oil pits, processing and recycling of oil sludge, lands rehabilitation and activation of local soil biocenosis by introducing hydrocarbonoxidizing microflora [1].

Conclusions. High concentrations of benzpyrene in soil, exceeding the value of MPC, indicate the persistent contamination of the soil horizon with polycyclic aromatic hydrocarbons and the slow process of soil selfpurification. 
High levels of carcinogenic health risk (1.08 $\mathrm{x} 10^{-3}-6.55 \times 10^{-3}$ ) are due to the high content of benzpyrene in soil, which is absolutely unacceptable for the population health. As the distance from Oil Refinery increases in the eastern and southeastern directions, an increase in the content of benzpyrene in soil is noted, which can negatively affect the health of Novokuibyshevsk' population at eventual reduction of the Oil Refinery' sanitary-hygienic zone.

\section{References}

1. Bioremediacija neftezagrjaznennyh pochv putem stimulirovanija mestnogo pochvennogo mikrobiocenoza: Grantovyj proekt № 97-04-50148 [Bioremediation of contaminated soils by stimulating the local soil microbiocenosis. Grant project Number 97-04-50148]. In: I.G. Kalachkina ed, supported by the Russian Federal Property Fund. Available at: http: //www.rfbr.ru/rffi/ru/project_search/o_151708 (09.09.2016) (in Russian).

2. Galiulin R.V., Galiulina R.A., Bashkin V.N. Ochistka pochvy ot nefti kak sposob zashhity gruntovyh vod ot zagrjaznenija [Cleaning of soil from oil as method of ground waters protection against contamination]. Vodoochistka. Vodopodgotovka. Vodosnabzhenie, 2015, vol. 95, no. 11, pp. 22-25 (in Russian).

3. Kryatov I.A., Tonkopij N.I., Vodjanova M.A., Ushakova O.V., Doner'jan L.G., Evseeva I.S., Matveeva I.S., Ushakov D.I. Garmonizacija gigienicheskih normativov dlja prioritetnyh zagrjaznenij pochvy s mezhdunarodnymi rekomendacijami [Scientific evidence for hygienic standards harmonized with international recommendations for priority polluitions of soils]. Gigiena $i$ sanitarija, 2015, vol. 94, no. 7, pp. 4248 (in Russian).

4. GN 2.1.7.2041-06. Predel'no dopustimye koncentracii (PDK) himicheskih veshhestv v pochve [Hygienic Standard 2.1.7.2041-06. Maximum permissible concentrations (MPC) of chemicals in soils]. Available at: http: //docs.cntd.ru/document/901966754 (09.09.2016) (in Russian).

5. GOST 17.4.4.02-84. Ohrana prirody. Pochvy. Metody otbora i podgotovki prob dlja himicheskogo, bakteriologicheskogo, gel'mintologicheskogo analiza [Nature preservation. Soils. Sampling techniques and samples preparation for chemical, bacteriological, and helminthological analysis: State Standard 17.4.4.02-84]. Moscow, Standartinform publ., 2008, 7 p. (in Russian).

6. D'yachenko V.V., Matasova I.Ju. Zagrjaznenie i dinamika mikrojelementov v pochvah juga Rossii [Pollution with trace elements and their dynamics in soils of southern Russia]. Geojekologija, inzhenernaja geologija, gidrogeologija, geokriologija, 2015, no. 4, pp. 324-332 (in Russian).

7. Kirienko O.A., Imranova E.L. Vlijanie zagrjaznenija pochvy nefteproduktami na sostav mikrobnogo soobshhestva [Effect of soil contamination with oil products on the composition of microbial community]. Vestnik Tihookeanskogo gosudarstvennogo universiteta, 2015, no. 3, pp. 79-86 (in Russian).

8. Kotel'nikova I.M., Sergeeva A.G. Ocenka zagrjaznenija pochv g. Blagoveshhenska policiklicheskimi aromaticheskimi uglevodorodami [Pollution assessment of polycyclic aromatic hydrocarbons in urban soil of Blagoveshchensk] Problemy jekologii Verhnego Priamur'ja, 2013, vol. 15, pp. 8-17 (in Russian).

9. Kuritsyn A.V., Kuritsyna T.V., Kataeva I.V. Bioremediacija neftezagrjaznennyh gruntov na tehnologicheskih ploshhadkah [Bioremediation of petropolluted soils on technological platforms]. Izvestija Samarskogo nauchnogo centra Rossijskoj akademii nauk, 2011, vol. 13, no. 1-5, pp. 1271-1273 (in Russian).

10. Mitrakova N.V., Shestakov I.E. Issledovanie ustojchivosti temno-seryh pochv Permskogo kraja metodom biotestirovanija pri zagrjaznenii pochv tjazhelymi metallami [Research of perm region soils resistance by biotesting methods for heavy metals polluted soils]. Antropogennaja transformacija prirodnoj sredy, 2015, no. 1, pp. 143-147 (in Russian).

11. Dabahov M.V., Dabahova E.V., Titova V.I., Oreshkova N.A. Osobennosti tehnogennoj transformacii pochv Nizhnego Novgoroda [Special features of soil anthropogenic transformation in Nizhniy Novgorod]. Agrohimicheskij vestnik, 2011, no. 2, pp. 21-23 (in Russian). 
12. Chertes K.L., Safonova N.A., Beljakov A.V., Shterenberg A.M. Proekt kompleksa shtabel'nosloevoj biodestrukcii neftesoderzhashhih othodov AO «Novokujbyshevskij NPZ» [Stacked-layered biological destruction of oil-containing wastes: a project by "Novokuybyishevskiy oil-refinery plant JSC"]. Vestnik SGASU. Gradostroitel'stvo i arhitektura, 2016, vol. 22, no. 1, pp. 58-62 (in Russian).

13. Rukovodstvo po ocenke riska dlja zdorov'ja naselenija pri vozdejstvii himicheskih veshhestv, zagrjaznjajushhih okruzhajushhuju sredu R 2.1.10.1920-04 [Guide to health risk assessment when exposed to chemicals polluting the environment 2.1.10.1920-04]. Moscow, Federal'nyj centr Gossanjepidnadzora Minzdrava Rossii publ., 2004, 143 p. (in Russian).

14. Smirnova T.S., Panina Ju.Ju. Monitoring uglevodorodnogo zagrjaznenija pochvy posredstvom analiza ejo fermentativnoj aktivnosti [Monitoring of soil hydrocarbon contamination by analysis of its enzymatic activity]. Zashhita okruzhajushhej sredy v neftegazovom komplekse, 2015, no. 12, pp. 33-38 (in Russian).

Suchkov V.V., Khotimchenko S.A., Sazonova O.V., Gorbachev D.O., Ryazanova T.K., Semaeva E.A. Population health risk related to increased content of benzpyrene in soil. Health Risk Analysis, 2017, no. 2, pp. 61-67. DOI: 10.21668/health.risk/2017.2.07.eng

Received: 02.02.2017

Accepted: 04.05.2017

Published: 30.06 .2017 